\title{
A RAGE Based Strategy for the Genome Engineering of the Human Respiratory Pathogen Mycoplasma pneumoniae
}

\author{
Luis Garcia-Morales, Estelle Ruiz, Géraldine Gourgues, Fabien Rideau, Carlos Piñero-Lambea, \\ Maria Lluch-Senar, Alain Blanchard, and Carole Lartigue*
}

Cite This: ACS Synth. Biol. 2020, 9, 2737-2748

Read Online

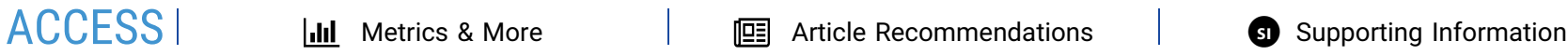

ABSTRACT: Genome engineering of microorganisms has become a standard in microbial biotechnologies. Several efficient tools are available for the genetic manipulation of model bacteria such as Escherichia coli and Bacillus subtilis, or the yeast Saccharomyces cerevisiae. Difficulties arise when transferring these tools to nonmodel organisms. Synthetic biology strategies relying on genome transplantation (GT) aim at using yeast cells for engineering bacterial genomes cloned as artificial chromosomes. However, these strategies remain unsuccessful for many bacteria,

MPN genome engineering in the platform of choice Exchange in MPN recipient cells including Mycoplasma pneumoniae (MPN), a human pathogen infecting the respiratory tract that has been extensively studied as a model for systems biology of simple unicellular organisms. Here, we have designed a novel strategy for genome engineering based on the recombinase-assisted genomic engineering (RAGE) technology for editing the MPN genome. Using this strategy, we have introduced a $15 \mathrm{kbp}$ fragment at a specific locus of the MPN genome and replaced $38 \mathrm{kbp}$ from its genome by engineered versions modified either in yeast or in E. coli. A strain harboring a synthetic version of this fragment cleared of 13 nonessential genes could also be built and propagated in vitro. These strains were depleted of known virulence factors aiming at creating an avirulent chassis for SynBio applications. Such a chassis and technology are a step forward to build vaccines or deliver therapeutic compounds in the lungs to prevent or cure respiratory diseases in humans. KEYWORDS: Mycoplasma pneumoniae (MPN), transformation-associated recombination-cloning (TAR-cloning), recombinase-assisted genomic engineering (RAGE), Saccharomyces cerevisiae, genome editing, phage recombinases

$S^{3}$ ynthetic biology is an emerging scientific discipline that aims to (re)design living organisms for specific purposes in fields like medicine, agriculture, manufacturing, and environment preservation. Model microorganisms, such as Escherichia coli,Bacillus subtilis, and Saccharomyces cerevisiae, are often chosen as the starting material to build a chassis in which the addition of different genetic blocks would enhance the organism capabilities. These model organisms show a robust fast growth in axenic conditions, they are harmless to humans and the environment, and the extensive work performed on genetic manipulation tools have led to a standardization of components. ${ }^{1}$ However, engineered organisms often fail to function as predicted due to unknown interactions between the new components and the host system. In this sense, a promising strategy would be constructing a streamlined cellular chassis close to a minimal cell. Such a platform would allow a complete tailoring of the cellular processes to execute the desired functions of the engineered cell. ${ }^{2-5}$ In this endeavor, the first step was to identify the minimal set of genes to sustain cellular life. $^{6-9}$ On the basis of this information, the next step was to remove nonessential genes in a process that resulted in the downsizing of minimal bacterial genomes like the ones found within the Mollicutes class. ${ }^{9,10}$ Remarkably, one of the bacterial cells that was obtained replicated with a genome of only $531 \mathrm{kbp} .^{9}$

Mycoplasma pneumoniae (MPN) is a wall-less bacterium and has one of the smallest genomes found in organisms capable of replication in an axenic medium with only $816 \mathrm{kbp} .{ }^{11}$ This bacterium causes human respiratory diseases including community-acquired pneumonia. ${ }^{12}$ Because of its reduced biosynthetic capabilities, this bacterium relies highly on its host for many nutrients such as lipids, amino acids, and vitamins. ${ }^{13}$ MPN has been the subject of many OMICS studies due to its apparent genomic simplicity, including whole genome sequencing, ${ }^{11}$ proteomics, ${ }^{14}$ transcriptomics, ${ }^{15}$ and metabolomics. ${ }^{16}$ Therefore, MPN is an interesting bacterial model as the starting material for a chassis cell. Given its natural tropism for the human respiratory tract, this chassis could be grafted with selected epitopes from respiratory pathogens, i.e., SARS-CoV2,

Received: May 14, 2020

Published: October 5, 2020 
to be used as a vaccine or by adding whole synthetic pathways to deliver therapeutic molecules directly in the lungs for the treatment of many respiratory diseases. ${ }^{17}$ Therefore, MPN is an interesting bacterial model as the starting material for a chassis cell. However, genome engineering is pivotal for these studies and the tools for genome grafting of MPN are particularly limited. Here we present a new genome engineering strategy that represent a stepping stone toward the use of MPN in such therapeutic applications.

Until now, mutagenesis of MPN has almost exclusively been accomplished by random transposition, introducing foreign DNA or disrupting endogenous genes. This random mutagenesis technology has been used successfully to provide a list of nonessential genes in $\mathrm{MPN}^{18,19}$ and to carry out a limited number of functional genomic studies. ${ }^{20,21}$ Unlike its close relative Mycoplasma genitalium, where gene replacement by homologous recombination has become a useful tool for genome editing, ${ }^{2-26}$ only one report showing extremely low efficiency of homologous recombination in MPN has been published. ${ }^{27}$ Recently, gene replacement in MPN has been improved by using the heterologous recombinase GP35, found in the Bacillus subtilis phage SPP $1,{ }^{28}$ and ssDNA as a template for recombination. ${ }^{17}$ This strategy has proven to be efficient to accomplish directed mutagenesis and can be combined with CRISPR/Cas9 counterselection for marker-less mutagenesis. ${ }^{17}$ Although this approach is a great improvement, it has its own limits. Specifically, while extremely useful for the generation of point mutations or small deletions, its performance is drastically reduced when large deletions (i.e., $>2 \mathrm{~kb}$ ) are pursued. Moreover, each modification can only be obtained one at a time. ${ }^{17}$ In order to accumulate the mutations needed for chassis design, other techniques of whole genome engineering are required.

An original strategy using yeast Saccharomyces cerevisiae as an intermediate host for the engineering of a whole bacterial genome was developed. This consists of cloning a bacterial genome into yeast cells, modifying it with the efficient genome editing tools available in these cells, ${ }^{29,30}$ and transplanting it back to bacterial cells. ${ }^{31-33}$ This is now the state-of-the-art technology for whole genome engineering of a number of ruminant-pathogenic mycoplasma species. ${ }^{34}$ In an attempt to transfer this strategy to MPN, we have cloned and edited the genome of MPN into yeast cells in one step using a novel technique known as CReasPy-cloning. ${ }^{35}$ However, our efforts to transplant the edited MPN genomes back into a mycoplasma recipient cell have been unsuccessful so far. To find a way of bypassing this step of genome transplantation (GT), we have designed a new strategy, whose general scheme is shown in Figure 1. First, a large fragment of MPN genomic DNA is captured in a shuttle vector in yeast (TAR cloning, Figure 1A). Then, the genome can be edited by using the available yeast engineering tools. After editing, DNA can be recovered from yeast and be transformed in E. coli for further modifications and amplification (Figure 1B). Finally, the DNA is introduced back into MPN by using a site-specific recombinase (i.e., Cre), and lox sites that were placed into MPN chromosome with the GP35 recombinase (RMCE, Figure 1C). The combination of yeast capturing and RMCE has been used previously to insert large fragments of DNA in several undomesticated bacteria in a process called (chassisindependent) recombinase-assisted genomic exchange (RAGE or CRAGE). ${ }^{36-38}$

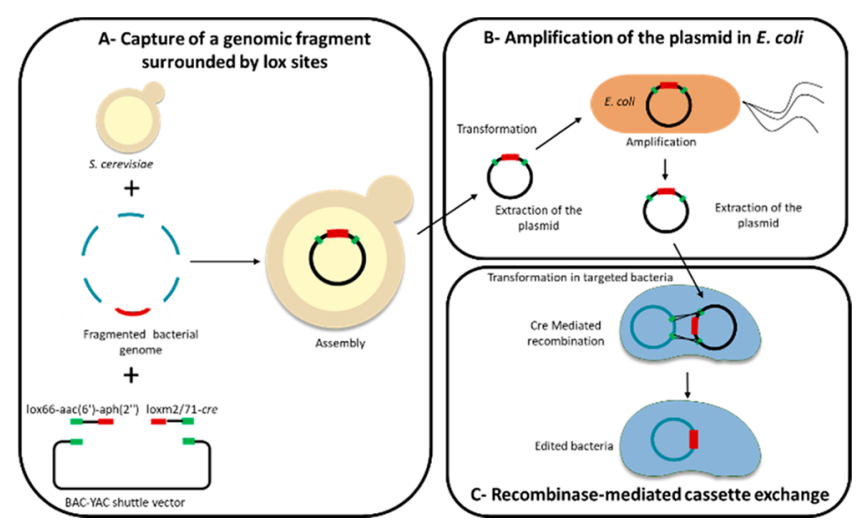

Figure 1. General scheme of a RAGE-based engineering cycle of MPN. (A) A BAC-YAC shuttle vector able to maintain a large fragment of DNA in S. cerevisiae and E. coli is cotransformed with a mixture of fragmented bacterial genomic DNA and two PCR products containing a bacterial selection marker (i.e., aac $\left(6^{\prime}\right)$-aph $\left(2^{\prime \prime}\right)$, which confers resistance to aminoglycosides) and a gene coding for a sitedirected recombinase (i.e., cre), respectively. These PCR products incorporate incompatible recombination sites that will be used for the recombinase-mediated cassette exchange (RMCE) (i.e., lox66 and loxm2/71) and the homology regions that allow the assembly in yeast. (B) The assembled plasmid is extracted and transformed in an E. coli strain, which allows a larger production of the plasmid. (C) By $\mathrm{RMCE}$, the cloned DNA fragment is incorporated or substitutes a part of the genome in the recipient bacteria, which has compatible recombination sites with those in the plasmid (i.e., lox71 and loxm2/ 66).

In this study, following the work performed by others, ${ }^{36-38}$ we introduced a large DNA fragment at a specific location in the genome of the genetically intractable organism MPN. Prompted by the high efficiency of this technique, we explored the potential of RAGE to perform other modifications than DNA insertions. To this end, we successfully exchanged a 38 kbp portion of the MPN genome by its counterpart edited in yeast or in E. coli, demonstrating that RAGE can also be used to replace large genomic regions and delete genes. This new application of the RAGE also allowed us to build a MPN strain, in which the $38 \mathrm{kbp}$ genomic fragment was entirely replaced by a $\sim 22 \mathrm{kbp}$ synthetic DNA piece made of essential genes assembled in vitro as it was accomplished in several GTbased experiments. ${ }^{9,31-33}$ This strain has been depleted of four virulence factors described previously in MPN, thus paving the way toward building a chassis to be used as engineered live biotherapeutics to treat human respiratory diseases. Furthermore, the strategy proposed here is a welcome alternative for intractable bacteria for which GT is not yet feasible, enhancing the current genetic toolbox and opening new possibilities in the functional genomics field.

\section{RESULTS}

Insertion of a $15.3 \mathrm{kbp}$ DNA Fragment in a Targeted Location of the MPN Genome. The insertion of large DNA fragments into targeted locations of the MPN genome could be accomplished by coupling TAR cloning in yeast cells with recombinase-mediated cassette exchange (RMCE) in a recipient MPN cell containing a suitable landing pad. To evaluate the feasibility of this strategy, we chose to duplicate the $s 10$ ribosomal protein operon $(15.3 \mathrm{kbp}$, encompassing genes from mpn164 to mpn192, which are involved in gene expression) by introducing an extra copy of this operon in the 

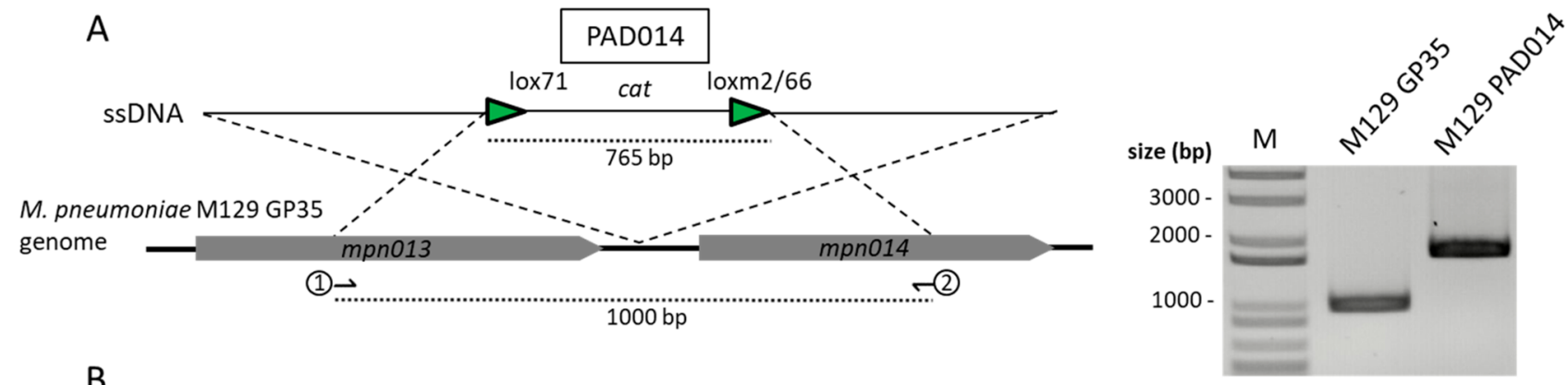

B

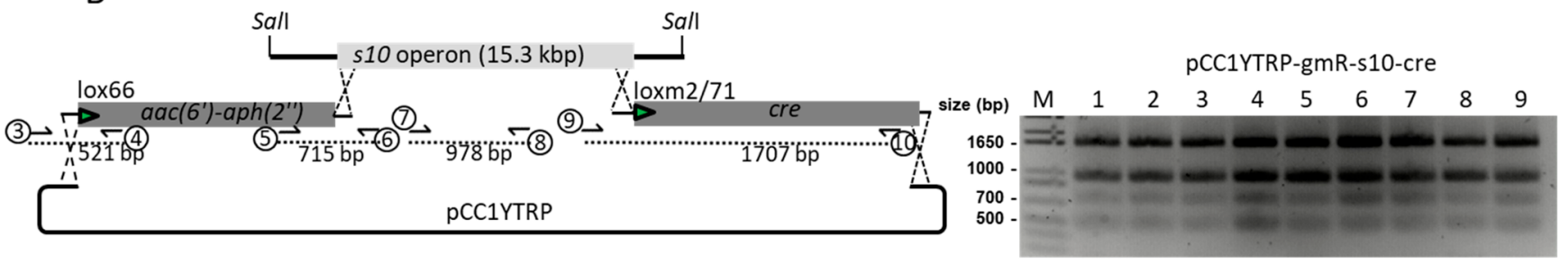

C

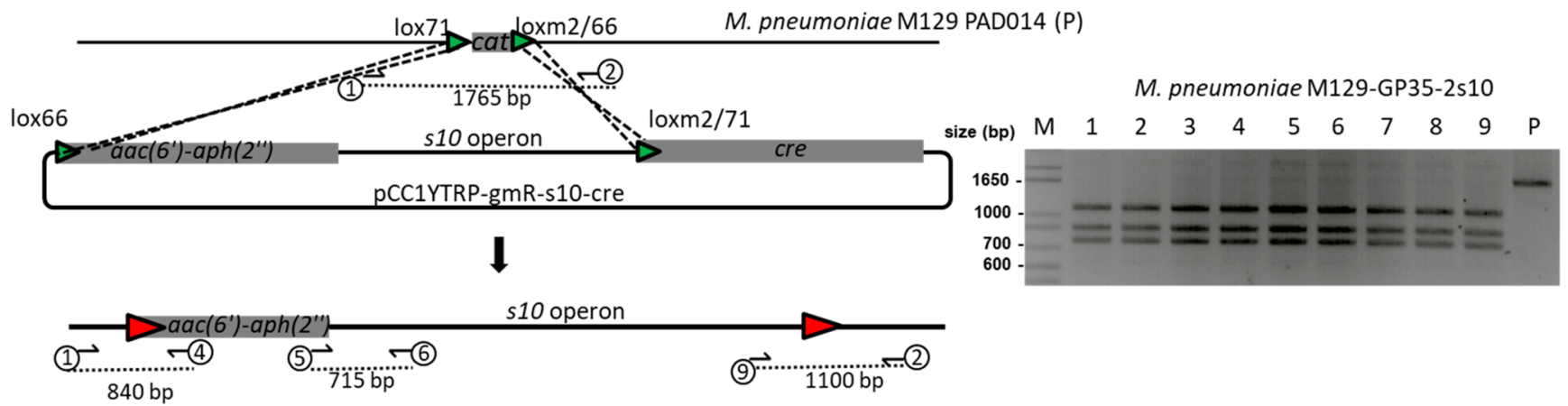

Figure 2. Duplication of the endogenous $s 10$ ribosomal protein operon in the intergenic region between the loci $m p n 013$ and $m p n 014$. (A) A single-stranded DNA, composed of the landing pad PAD014 (765 bp) flanked by 500 bp homology arms corresponding to regions upstream and downstream the insertion site located in the intergenic region between the loci mpn013 and mpn014, was transformed in a MPN M129 strain expressing the GP35 recombinase. This recombinase promotes the insertion of the landing pad in the intended site by a double recombination event. A PCR amplification with primers 1 and 2 shows a band of $1000 \mathrm{bp}$ in the M129 GP35 strain and an increment to 1765 bp in the chloramphenicol resistant MPN M129 PAD014 strain due to the presence of the landing pad. (B) A plasmid containing the pCC1YTRP backbone, the $s 10$ operon $(15.3 \mathrm{kbp})$, and two PCR products (the aminoglycoside resistance coding gene $\left(a a c\left(6^{\prime}\right)-a p h\left(2^{\prime \prime}\right)\right)$ and the cre recombinase coding gene) was assembled by cotransformation in S. cerevisiae cells. The two PCR fragments contain the incompatible lox sites and the 60 bp homology ends needed for the capture of the $s 10$ operon and the assembly of the pCC1YTRP-gmR-s10-cre plasmid. The multiplex PCR with primers 3-10 (4 pairs) confirmed the correct assembly in 9 yeast clones, in which the $s 10$ operon was obtained from a genomic DNA extraction either from MPN cells (clones 1-4), MPN cells embedded in agarose plugs (clones 5-8), or yeast cells containing the MPN genome embedded in agarose plugs (clone 9). The expected sizes of the bands are 1707, 978, 715, and 521 bp. (C) Upon transformation of the pCC1-gmR-s10-cre plasmid into MPN M129 PAD014 recipient cells, a double recombination event between lox66-lox 71 and loxm2/66-loxm2/71 sites promoted by the Cre recombinase led to the insertion of the $s 10$ operon in the intergenic region between mpn013 and mpn014. Several gentamycin resistant clones were analyzed by multiplex PCR with primers $1,2,4,5,6$, and 9, showing the insertion in the intended site. The expected sizes of the bands are 1100, 840, and $715 \mathrm{bp}$. The parental clone (MPN M129 PAD014, P), used as control, shows only one PCR band of 1765 bp corresponding to the amplification with the primers 1 and 2 .

intergenic region, close to the oriC, between the mpn013 and mpn014 genes. The first step was to construct a recipient strain containing a landing pad for RMCE, which consisted of a chloramphenicol resistance marker (cat) flanked by two incompatible lox sites (lox71 and loxm2/66). This landing pad was inserted in the intended location by homologous recombination mediated by the GP35 recombinase. ${ }^{17}$ A single chloramphenicol resistant colony was detected, and the presence of the landing pad in the intended location was confirmed by PCR analysis using oligonucleotides Pad014LH/ 5 and Pad014RH/3 (Figure 2A). The resulting MPN M129 PAD014 strain possesses a landing pad that can be exchanged by any DNA fragment surrounded by the corresponding incompatible lox66 and loxm $2 / 71$ sites by using the Cre recombinase. The sequence for all lox sites used in this work is found in Table S1.

Since yeast recombination is more efficient on linear DNA, ${ }^{39,40}$ we tried different methods to linearize the MPN genome prior to the yeast transformation. Mechanical disruption of MPN gDNA in solution by pipetting up and down several times should generate random fragments of different desired sizes. ${ }^{40}$ First, we tried to pipet the gDNA solution 18 and 22 times, following the indications described by ref 40 to obtain fragments around $20-50 \mathrm{kbp}$. However, no positive colonies were found out of 60 transformant colonies tested. Then, we also tested linearizing gDNA by restriction 
digestion using SalI, given that there is a site 623 bp upstream and 426 bp downstream the region to be captured. Restriction linearization showed better assembly efficiency (4 positive clones from 20 transformant colonies), probably because the cut sites are more specific than in gDNA fragmented mechanically. Lastly, we tried to use MPN gDNA embedded in agarose plugs. Agarose plugs are used to keep chromosomal DNA intact. We obtained 1 out of 30 positive clones when pipetting 18 times, and 3 out of 10 positive clones when linearizing with SalI. We also demonstrated we are able to use MPN gDNA previously cloned in yeast by CReasPy-cloning and further embedded in agarose plugs. We obtained 1 out of 10 positive clones when linearizing with SalI. Correct assembly of the pCC1YTRP-gmR-s10-cre plasmid was screened by PCR using oligonucleotides MultS107 and CreS10/3 and confirmed by multiplex PCR (Figure 2B). A summary of all yeast assemblies performed in this work is presented in Table 1 .

Table 1. Assembly of pCC1 Derivatives by TAR Cloning in Yeast

\begin{tabular}{|c|c|c|c|}
\hline assembled part & $\begin{array}{c}\text { genomic DNA } \\
\text { origin }\end{array}$ & $\begin{array}{l}\text { genomic } \\
\text { fragmentation }\end{array}$ & $\begin{array}{c}\text { positive clones/ } \\
\text { analyzed }\end{array}$ \\
\hline $\mathrm{s} 10(15.3 \mathrm{kbp})$ & MPN cells & $\begin{array}{l}\text { mechanical } \\
\text { shearing }\end{array}$ & $0 / 60$ \\
\hline s10（15.3 kbp） & MPN cells & SalI & $2 / 20$ \\
\hline $\mathrm{s} 10(15.3 \mathrm{kbp})$ & $\begin{array}{l}\text { MPN agarose } \\
\text { plugs }\end{array}$ & $\begin{array}{l}\text { mechanical } \\
\text { shearing }\end{array}$ & $1 / 30$ \\
\hline s10 (15.3 kbp) & $\begin{array}{l}\text { MPN agarose } \\
\text { plugs }\end{array}$ & SalI & $3 / 10$ \\
\hline $\mathrm{s} 10(15.3 \mathrm{kbp})$ & $\begin{array}{l}\text { yeast agarose } \\
\text { plugs }\end{array}$ & SalI & $1 / 10$ \\
\hline $\begin{array}{l}\text { mpn372-mpn } 400 \\
(37.8 \mathrm{kbp})\end{array}$ & $\begin{array}{l}\text { yeast agarose } \\
\text { plugs }\end{array}$ & NotI-XhoI & $1 / 230$ \\
\hline$\underset{(36 \mathrm{kbp})}{\Delta \operatorname{mpn} 372-\mathrm{mpn} 400}$ & $\begin{array}{l}\text { yeast agarose } \\
\text { plugs }\end{array}$ & NotI-XhoI & $3 / 20$ \\
\hline $\begin{array}{l}\operatorname{mpn} 372-\Delta \operatorname{mpn} 400 \\
(36 \mathrm{kbp})\end{array}$ & $\begin{array}{l}\text { yeast agarose } \\
\text { plugs }\end{array}$ & NotI-XhoI & $6 / 20$ \\
\hline
\end{tabular}

One correct pCC1YTRP-gmR-s10-cre construction was extracted from the yeast cells and electroporated into E. coli EPI300 (Figure 1B) This latter strain allows the maintenance of large plasmids and the induction for production of larger quantities of DNA with enough quality to transform it into MPN recipient cells. Finally, the vector was electroporated into recipient cells of MPN M129 PAD014 strain (Figure 1C). Once inside, the site-directed recombinase Cre should promote the recombination between the lox66 and lox 71 sites, and between the loxm2/66 and loxm $2 / 71$ sites, respectively, leading to the cassette exchange. After transformation, 20 gentamycin resistant colonies were picked and screened by multiplex PCR. All had inserted the $s 10$ operon at the expected location, right between mpn013 and mpn014 loci, and lost the chloramphenicol resistant marker (Figure 2C). This is, to our knowledge, the largest nonrandom DNA insertion obtained in any mycoplasma species.

Exchange of a $37.8 \mathrm{kbp}$ Genomic Region in MPN Cells. The high efficiency of our previous work inserting DNA by RMCE using the Cre recombinase encouraged us to use this technology to exchange a region of genomic DNA by an equivalent region cloned in yeast. This strategy would allow the use of yeast as a platform to perform genome editing of MPN. To test this possibility, we selected a $37.8 \mathrm{kbp}$ region from the mpn 372 to the $m p n 400$ genes. This region contains essential genes, nonessential genes (including virulence related genes), and fitness genes. ${ }^{18}$ Remarkably, two genes encoding major virulence factors, mpn372 and mpn400, are found in this region. ${ }^{41-43}$ Two different landing pads are needed to perform a replacement in the genome. We started with the introduction of the landing pad PAD372, which includes a lox71 site and the tetracycline resistant marker $(\operatorname{tet}(\mathrm{M}))$, upstream of the mpn372 gene. However, no transformants were obtained after several attempts to insert this landing pad with the GP35 recombinase, probably because of the size of the tet $(\mathrm{M})$ marker. We tried to introduce this same landing pad in an MPN strain lacking two nucleases and two restrictases coding genes constructed also with the GP35 technology (Supplementary Figure S2). This latter strain was built in our laboratory with the aim of incrementing the transformation efficiency of MPN by reducing the degradation of the incoming DNA molecules. Although no significant transformation efficiency was observed when transforming with plasmid mini-transposons (data not shown), one transformant colony was found when transformed with the landing pad PAD372 and was confirmed by PCR (Supplementary Figure S3A). A second landing pad, the PAD400, including the cat marker and the loxm2/66 site, was introduced downstream the mpn 400 locus in this clone using the same recombinase. We analyzed 20 transformant colonies by PCR and all contained this second landing pad (Supplementary Figure S3B). As a result, this MPN M129 recipient strain has the region between loci $m p n 372$ and mpn400 surrounded by incompatible lox sites (Supplementary Figure S3C) and can be used for genome modifications purposes. A graphical representation showing the location of all the landing pads in the MPN genome is provided in Supplementary Figure S4.

The plasmid pCC1YTRP-gmR-37.8-cre was assembled in yeast as previously described, capturing the $37.8 \mathrm{kbp}$ region between the mpn372 and mpn 400 genes (Figure 1A). MPN genomic DNA embedded in agarose plugs was linearized using NotI and XhoI restriction enzymes. These restriction sites are located $1720 \mathrm{bp}$ upstream and $3863 \mathrm{bp}$ downstream from the captured region. We obtained 1 out of 230 positive yeast clones containing the assembled plasmid and confirmed by multiplex PCR. After amplification in E. coli EPI300 cells (Figure 1B), this vector was finally transformed in the recipient strain MPN M129 PAD372 PAD400, where Cre mediated recombination between chromosomal and plasmid lox sites promoted the exchange of the original $37.8 \mathrm{kbp}$ chromosomal DNA fragment by the same region present in the plasmid (Figures $1 \mathrm{C}$ and $3 \mathrm{~A}$ ). To confirm the exchange, PCR were designed to check the incorporation of the gentamycin resistance gene in the intended site and the loss of tetracycline and chloramphenicol resistance genes. Out of the 24 colonies tested, 3 were found to have exchanged the $37.8 \mathrm{kbp}$ region (Figure 3B and 3C).

Editing MPN Genome Using Yeast. On the basis of this result, this novel strategy should allow genetic modifications in a specific region of the genome of MPN, using yeast as a platform for mutagenesis. Using the new CReasPy-cloning technology, our group was able to clone and modify the whole MPN M129 genome in S. cerevisiae cells. ${ }^{35}$ In particular, genes $m p n 372$ or $m p n 400$ were deleted individually or in duo. Yeast clones carrying MPN genomes with individual deletions were selected to repeat the above-mentioned experiment. These genomes contained the elements required to maintain circular DNA in yeast cells (CEN6, ARSH4, and HIS3) within the $m p n 372$ or mpn400 loci. To not duplicate the CEN6 and 


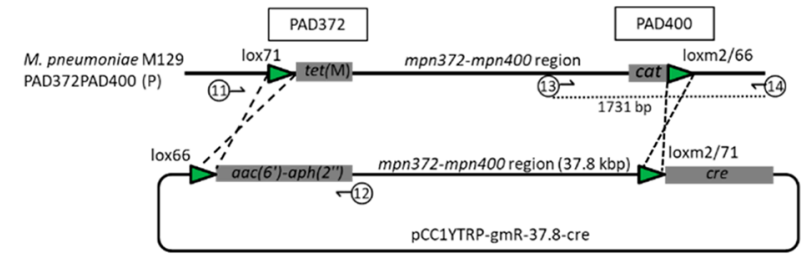

I Cre

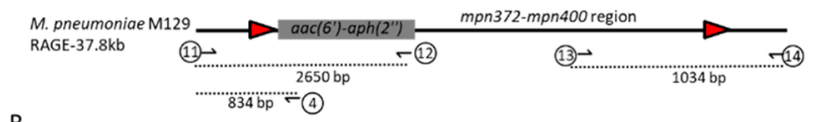

B

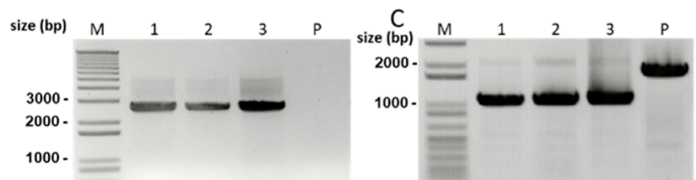

D

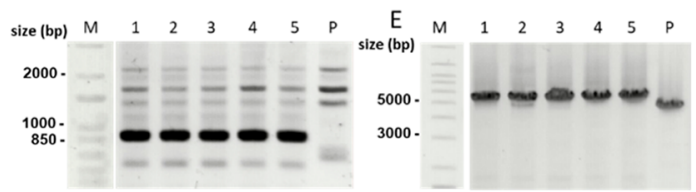

$\mathrm{F}$

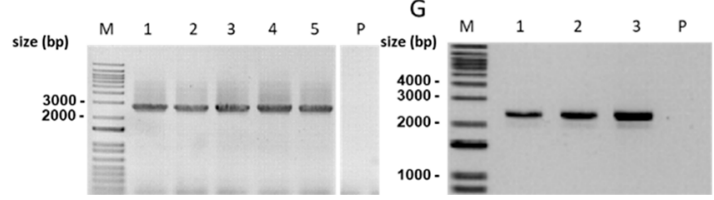

Figure 3. Exchange of a genomic region. (A) The recombinase activity of Cre produces the exchange between the regions surrounded by the lox sites present in the parental strain M. pneumoniae M129 PAD372PAD400 (P) and in the pCC1YTRPgmR-37.8-cre plasmid. This exchange is coupled with the loss of the tet $(\mathrm{M})$ and cat antibiotic resistant markers and the incorporation of the $\operatorname{aac}\left(6^{\prime}\right)-a p h\left(2^{\prime \prime}\right)$ aminoglycosides resistant marker. (B) PCR analysis of 3 clones obtained after transformation with the pCC1YTRP-gmR-37.8-cre using primers 11 and 12. This PCR confirmed the presence of the $\operatorname{aac}\left(6^{\prime}\right)-\operatorname{aph}\left(2^{\prime \prime}\right)$ marker in the intended location ( $2650 \mathrm{bp}$ band), substituting the tet $(M)$ marker, in the clones where the exchange has occurred, while it is absent in the parental strain (P). (C) PCR analysis of 3 clones obtained after transformation with the pCC1YTRP-gmR-37.8-cre using primers 13 and 14. This PCR confirmed the loss of the cat marker (1034 bp band) present in the parental strain (P) (1731 bp band). (D) PCR analysis of 5 clones obtained after transformation with the pCC1gmR-37.8Dmpn372-cre using primers 11 and 4. This PCR confirmed the presence of the $\operatorname{aac}\left(6^{\prime}\right)-\operatorname{aph}\left(2^{\prime \prime}\right)$ marker in the clones where the exchange has occurred ( $834 \mathrm{bp}$ ), generating MPN $\Delta$ mpn372 deficient strains, while it is absent in the parental strain (P). (E) PCR analysis of 5 clones obtained after transformation with the pCC1-gmR$37.8 \Delta$ mpn400-cre using primers Verif-MPN400 (the sequence of primer 13 is absent in the mutant strain) and 14. This PCR confirmed the loss of mpn400 and cat marker and the incorporation of the CEN6, ARSH4, HIS3 elements and puromycin resistant marker (5400 bp band), resulting in MPN $\Delta m p n 400$ deficient strains. The cat marker is present in the parental strain (P) (4766 bp band). (F) PCR analysis of the MPN $\Delta m p n 372$ deficient strains generated using the pCC1YTRP-gmR-37.8 $\Delta$ mpn372-cre created with the $\lambda$ Red system in E. coli. As in (B) the amplification of a $2650 \mathrm{bp}$ band with primers 11 and 12 reveals the exchange of the $37.8 \mathrm{kbp}$ region by the modified region. (G) PCR analysis with primers 11 and 12 of $3 \mathrm{MPN}$ colonies transformed with the synthetic $24.1 \mathrm{kbp}$ (colony 1) and $22.4 \mathrm{kbp}$ (colonies 2-3) fragments $(2650 \mathrm{bp})$. This PCR demonstrate exchange with the synthetic fragments.
ARSH4 regions, the original pCC1FOS plasmid was used, instead of the pCC1YTRP, for the TAR assembly of the resulting $\mathrm{pCC} 1$-gmR-37.8 $\Delta \mathrm{mpn} 372$-cre and $\mathrm{pCC} 1$-gmR$37.8 \Delta$ mpn 400 -cre plasmids. Both YAC-BAC plasmids were correctly assembled in yeast. Interestingly, we could observe that the efficiency of the plasmid assembly was higher when these yeast elements were cloned in the targeted genomic region rather than in the plasmid backbone. Indeed, 3 out of 20 positives clones were obtained for the assembly of the pCC1-gmR-37.8 $\Delta$ mpn372-cre and 6 out of 20 positive clones for the assembly of the pCC1-gmR-37.8 $\Delta$ mpn400-cre, in comparison with the 1 out of 230 positive clones obtained in the previous experiment (Table 1).

Once assembled in yeast and amplified in E. coli EPI300 cells, these plasmids were electroporated into MPN M129 PAD372 PAD400 recipient cells. Transformant colonies were isolated and analyzed by PCR. Seven out of the 7 colonies analyzed for the deletion of mpn372, and 6 out of the 6 colonies analyzed for the deletion of mpn400, did the exchange and showed the intended deletion by PCR (Figure 3D and Figure 3E, respectively, only 5 clones are shown). These results are therefore a proof that the succession of CReasPy-cloning, in-yeast TAR-cloning, and RMCE technologies can be used as an editing cycle of MPN cells.

Editing MPN Genome Using E. coli. Given that plasmids containing large MPN genomic fragments are able to be maintained both in $S$. cerevisiae and $E$. coli, we wanted to test BAC recombineering techniques over the pCC1YTRP-gmR37.8-cre plasmid. Being able to use E. coli as a platform for mutagenesis would actually not only enlarge the possibilities for MPN genome editing, but also strengthen the whole pipeline, notably by reducing the time required to obtain mutant strains with increasing modifications. To do so, the plasmid pCC1YTRP-gmR-37.8-cre was electroporated into E. coli SW105 cells. These cells, kindly provided by the Don L. Court laboratory, express the $\lambda$ Red recombination system cloned in their own chromosome under the control of the cI promoter. ${ }^{44}$ Following the instructions found in the literature ${ }^{45}$ we added a tet $A / \operatorname{sacB}$ cassette downstream the gene mpn372. ${ }^{46}$ Tetracycline resistant colonies were isolated, analyzed by PCR, and later transformed with the reparation oligonucleotides to remove the mpn372 gene and the tet $A / s a c B$ cassette (Figure S5). Sucrose resistant colonies were analyzed by PCR for the intended deletion and the resulting pCC1YTRP-gmR-37.8 $\Delta$ mpn372-cre plasmid. As previously, this plasmid was transformed into E. coli EPI300 cells for amplification and subsequently into MPN M129 PAD372 PAD400 recipient cells to get MPN mutants. Eight out of the 42 colonies analyzed for the deletion of mpn372 did the exchange and showed the intended deletion by PCR (Figure 3F).

Editing the MPN Genome Using Synthetic DNA. The use of synthetic DNA fragments would allow a faster accumulation of site-directed mutations than the aforementioned editing technologies. To test this possibility, we assembled in vitro two versions of the pCC1YTRP-gmR37.8-cre plasmid, each one lacking 13 nonessential genes from the same genomic region (mpn372 gene to the mpn 400 gene). The complete list of genes deleted in this experiment is provided in Table S2. Among these genes, the two genes encoding for virulence factors mpn372 and mpn 400 were deleted with the aim of building a harmless strain that can serve for SynBio applications. The genes were considered 
nonessential according to previous works on essentiality of genes in MPN, ${ }^{18,19}$ in M. genitalium, ${ }^{8,47}$ or in the previous synthetic minimized genome JCVI-syn3.0. ${ }^{9,48}$ However, we decided to keep all the genes coding for the pyruvate dehydrogenase complex in the edited MPN genome to keep a metabolic robustness. We assembled two versions that differ on the presence or deletion of the intergenic regions between mpn373-mpn374, mpn374-mpn375, and mpn375-mpn376. These regions have a total size of $1751 \mathrm{bp}$, which account for an unusually large noncoding DNA in the MPN genome. Hence, we used Gibson assembly to construct the two reduced versions of pCC1YTRP-gmR-37.8-cre: namely, pCC1-gmR24.1-cre, which includes the intergenic regions and a total of $24.1 \mathrm{kbp}$ between the heterospecific lox sites, and the pCC1gmR-22.4-cre, which does not include these regions and has a size of $22.4 \mathrm{kbp}$ (Figure S6). The assemblies were transformed into E. coli Epi300 for amplification and transformed into MPN M129 PAD372 PAD400 recipient cells. All selected positive clones from the two versions did the exchange (Figure 3G), but we were unable to isolate pure clones, since parental cells could be detected using another pair of primers (Supplementary Figure S7A-C). Sanger sequencing was performed on these clones, demonstrating the exchange for the synthetic fragment (Supplementary Figure S7D,E). This latter supposes the deletion of noncontinuous $15.4 \mathrm{kbp}$ from the genome of MPN in one step. A summary of the results of all RMCE experiments is found in Table 2 .

Table 2. Positive Clones in the Different RecombinaseMediated Exchanges

\begin{tabular}{|c|c|c|}
\hline recipient strain & vector & $\begin{array}{c}\text { positive clones/clones } \\
\text { analyzed }\end{array}$ \\
\hline M129 PAD014 & pCC1-gmR-S10-cre & $20 / 20$ \\
\hline $\begin{array}{l}\text { M129 } \\
\text { PAD372PAD400 }\end{array}$ & pCC1-gmR-37.8-cre & $3 / 24$ \\
\hline $\begin{array}{l}\text { M129 } \\
\text { PAD372PAD400 }\end{array}$ & 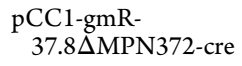 & $7 / 7$ \\
\hline $\begin{array}{l}\text { M129 } \\
\text { PAD372PAD400 }\end{array}$ & $\begin{array}{l}\text { pCC1-gmR- } \\
37.8 \Delta \mathrm{MPN} 400-\mathrm{cre}\end{array}$ & $6 / 6$ \\
\hline $\begin{array}{l}\text { M129 } \\
\text { PAD372PAD400 }\end{array}$ & pCC1-gmR-24.1-cre & $15 / 34$ \\
\hline $\begin{array}{l}\text { M129 } \\
\text { PAD372PAD400 }\end{array}$ & pCC1-gmR-22.4-cre & $85 / 170$ \\
\hline
\end{tabular}

\section{DISCUSSION}

The Mollicutes M. pneumoniae has been extensively studied and remains an interesting bacterial model given its small streamlined genome, its metabolic simplicity, and the fact that it is a human pathogen. ${ }^{49}$ The amount of OMICS data generated over the past 10 years is colossal and allows a better understanding of the organism. But more effective functional genomic studies are essential for an advanced characterization of the physiology of this bacterium and for its use as a potential chassis for therapy, and it has for long been hindered by the limitation of genetic engineering tools. The recent application of the GP35 recombinase allows gene replacements by homologous recombination. ${ }^{17}$ With this technology, researchers have recently succeeded in introducing site-directed mutations into MPN cells such as gene deletions, insertions or even point mutations on genetic markers. They have also succeeded in making marker-less, scar-less mutations by combining the GP35 mutagenesis with the CRISPR/Cas9based counterselection system.

However, GP35 technology has some limitations as stated by the authors. GP35 is a powerful tool to make insertions of around $2 \mathrm{kbp}$ maximum, with a large drop in efficiency for slightly larger inserts. ${ }^{17}$ As shown in this work, this technique allowed us to introduce landing pads, but the introduction of the tet $(\mathrm{M})$ marker for the PAD372, with a size of $1976 \mathrm{bps,}$ was challenging. To be able to introduce large DNA fragments into the chromosome of MPN is pivotal for its use as a chassis strain whether it be for vaccination purposes or as a drug delivery system. Indeed, such developments would require the introduction of antigen membrane exposition complexes or entire heterologous biosynthetic pathways for drug production, which will easily be far larger than $1 \mathrm{kbp}$.

In this work, we have adapted and modified the RAGE strategy $^{36-38}$ to be used in MPN. We used TAR cloning to catch in yeast a fragment of $15.3 \mathrm{kbp}$ genomic DNA into a plasmid between incompatible lox sites avoiding the use of large PCR amplifications, which can be a limiting step. This strategy allows us to capture targeted sequences of genomic DNA from different sources, such as extracted from the original bacteria or from genomic DNA cloned in yeast cells. We modified the pCC1Fos plasmid to stabilize large DNA fragments in both $S$. cerevisiae and E. coli similarly to previous works, ${ }^{50}$ and amplify it in E. coli to obtain sufficient amounts of plasmid for its electroporation into MPN cells. Hence, our results show that the combination of yeast assembly of YACBACs with Cre-based RMCE is a powerful and efficient tool to introduce large fragments of DNA into the genome of MPN into intended sites. For applications where the presence of an antibiotic resistance marker is undesired, an extra round of mutagenesis with GP35 and Cre-lox recombination can be used to remove the genetic marker. ${ }^{17}$

Deletion of genes and introduction of targeted point mutations using GP35 recombinase is also a breakthrough for the study of MPN. Given its reduced genome, the deletion of nonessential genes may lead in the generation of a minimal cell. However, deleting genes with this technology is very timeconsuming in steps like cloning and ssDNA preparation, and it does not allow targeting different mutation sites in one mutation cycle. For other mycoplasmas, it has been possible to clone and modify their genome in yeast cells and transplant it back into the original or different bacterial cells. ${ }^{31-34}$ We have reported recently the cloning and multiloci editing of MPN genome in yeast in one single step named CReasPy-cloning. ${ }^{35}$ However, no MPN transplants have yet been obtained despite our continuous efforts. To this date, GT into bacterial cells has been accomplished by using very tight PEG-based protocols, often different for each recipient cell. Many obstacles may explain these variations including the presence of nucleases or restrictases, ${ }^{51,52}$ or a cytoskeleton structure. ${ }^{53}$ For interspecies transplantation, it has been reported that at least a minimum of $90 \%$ of the core proteome should be shared between the DNA donor and the receptor cell. ${ }^{34}$ Here, we have developed a different strategy that uses an edited bacterial genome in yeast cells to introduce mutations into the recipient bacteria by "transplanting" only a portion of the genome using a sitedirected recombinase. This strategy combines the novel technologies of CReasPy-cloning, TAR-cloning, GP35 recombineering and RMCE, introducing a novel whole genome engineering avenue for these otherwise fastidious bacteria. We used it to delete the mpn372 gene, coding for the CARDS 
toxin, $^{41}$ and the mpn400 gene, coding for a homologous protein to the $M$. genitalium protein $\mathrm{M}$, an $\mathrm{IgG}$ binding protein $^{42}$ involved in immune evasion. Furthermore, we have used our new strategy with synthetic DNA and deleted 13 genes in one step while replacing 14 essential genes for synthetic counterpart. This demonstrates that MPN can use synthetic DNA inserted in its genome. However, we were unable to isolate pure clones just after transformation as the parental strain could also be detected in the samples. Our difficulty to isolate pure clones might be explained by (1) a decrease in fitness due to the removal of 13 genes in the mutant strains, (2) an increase of stickiness due to the disturbance created by the absence of MPN387, a component of the attachment organelle essential for gliding, (3) the frequent isolation of gentamycin spontaneous resistant colonies, or (4) a combination of these. ${ }^{19,54-56}$ Nevertheless, PCR and Sanger sequencing demonstrate that a number of cells have done the exchange (Supplementary Figure S7).

We performed these mutations on a strain constructed previously lacking also the nucleases coded in the mpn133 and mpn491 genes, which were described as virulence factors. ${ }^{51,52}$ Hence, we have constructed a potentially avirulent bacterial chassis and we have developed a strong technology to enhance it with specific payloads. This technology represents a true advance toward the long-term objective of engineering MPN for therapeutical purposes. Moreover, the paramount -OMICS data available from extensive previous studies of MPN will facilitate the design of future chassis strains in comparison to other bacteria found in the respiratory tract. We can envision, for example, to expose relevant epitopes from respiratory pathogens in its membrane, which could lead to a new generation of vaccines for lung diseases. This epitope exposition in the membrane can be hampered in many steps, but thanks to this new technology, the insertion of the large encoding genes is currently not a bottleneck. Another possibility would be to introduce, by using the RAGE strategy, large synthetic pathways to deliver therapeutic compounds directly in the lungs. The recent outbreak of the SARS-CoV2 demonstrates the need for developing such original strategies.

Such applications will require a robust tool of whole genome engineering that allows a rapid accumulation of directed mutations and even the synthesis of a part or the totality of its genome. The strategy presented here is a combination of existing tools that allowed unprecedented genome engineering in the intractable bacteria MPN. The RAGE technology has been used previously to insert large DNA fragments, such as biological gene clusters, in several bacterial strains, ${ }^{38}$ but to our knowledge, it has never been used to engineer a bacterial genome. Using this technology, we can now potentially modify the MPN genome to the same extent as to other mycoplasmas in which whole genome transplantation is possible. A similar approach to the one presented in this work has been recently used to recode $E$. coli by exchanging $100 \mathrm{kbp}$ fragments of genomic DNA by synthetic DNA using CRISPR/Cas9. ${ }^{57}$ Unlike with Cre recombinase, CRISPR/Cas9 does not leave a scar after the exchange. However, an efficient homologous recombination method, such as the $E$. coli $\lambda$ Red system, is needed to promote the cassette exchange, which limits its use in many bacterial species, including MPN. Cre recombinase, as well as other site-directed recombinases like Phi C31 or FLP, have been shown to be active in a number of bacterial species, but not many RMCE experiments have been performed in prokaryotes. ${ }^{58-61}$ However, it is a common technology used for engineering the genome of animal cells. ${ }^{62-65}$ In theory, this technology would be suited to any bacterial species for which the introduction of landing pads is possible. This also opens the possibility of creating and using YAC or BAC genomic DNA libraries of different bacteria to easily manipulate a desired fragment in yeast or in E. coli and introduce the engineered fragment in a receptor cell.

Editing the genome of MPN with this new strategy can be done in different steps (Figure 4). First, mutations can be

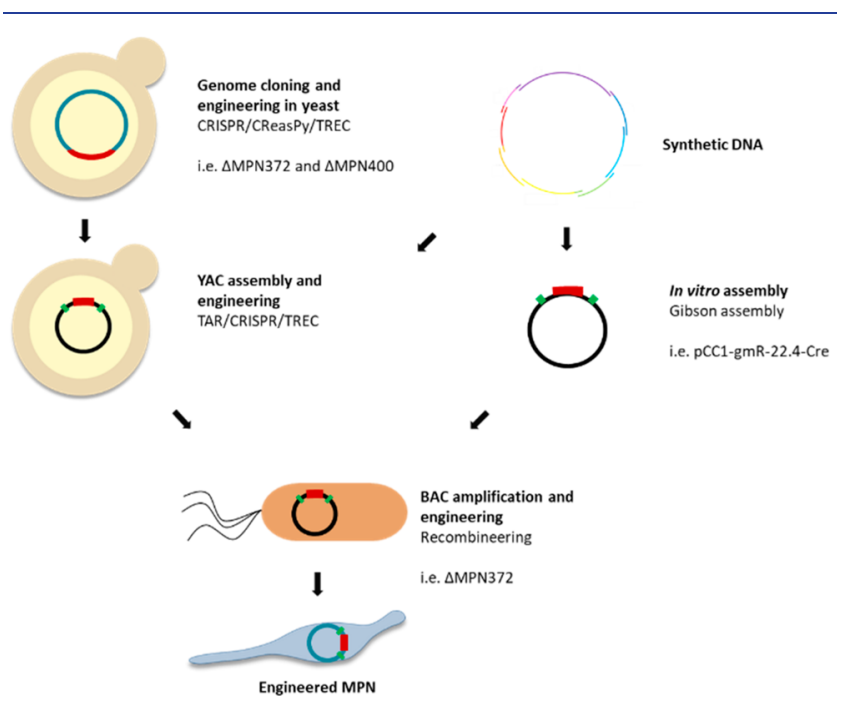

Figure 4. Scheme of the engineering strategy showing the different genetic tools available in each step. MPN mutant strains can be obtained by modifying the exchangeable region using yeast editing tools on a cloned MPN genome in yeast (CReasPy and CRISPR/ Cas9), or on the pCC1-derived plasmid (CRISPR/Cas9). Otherwise, the region can be synthesized chemically or can be modified using the $\lambda$ Red technology inE. coli (recombineering).

introduced in the step of cloning a bacterial genome in yeast by CReasPy. ${ }^{35}$ The use of CRISPR/Cas9 or the tandem repeat coupled with endonuclease cleavage (TREC) on the cloned bacterial genome would be also possible in this step. ${ }^{29,30}$ Second, a fragment of the genome extracted from the bacterial cells in the YAC-BAC shuttle vector is cloned. As an alternative to whole bacterial genome cloning, we could use CRISPR/ Cas9 in these YAC-BAC vectors. Hence, this strategy could be used to edit larger genomes for which the cloning step in yeast is challenging. Lastly, we can use $\lambda$ Red recombinase in $E$. coli on the YAC-BAC vector containing the fragment of MPN genome to introduce marker-less scar-less mutations. ${ }^{44}$ This latter possibility is the cheapest and the less time-consuming approach to edit the MPN genome using this platform.

Another novel possibility is the introduction of synthetic DNA into the genome of MPN or the exchange of a large genomic fragment for DNA synthesized de novo. This is extremely useful when pursuing the construction of a minimal genome containing only essential genes. We have succeeded to remove 13 noncontiguous nonessential genes from the genome of MPN in a single step, therefore validating the predictions of essentiality of these genes. $8,9,18,19,47,48$ Although this approach is still expensive, its simplicity and speed make it extremely valuable. GT-based technologies have permitted an equivalent whole genome engineering malleability in some species of mycoplasma. However, GT is feasible only in a small number of bacterial species. For this reason, previous efforts of genome 
Table 3. Yeast and Bacterial Strains Used in This Work

\begin{tabular}{|c|c|c|c|}
\hline species & strain & genotype & reference \\
\hline Saccharomyces cerevisiae & VL6-48N & MAT $\alpha$, his3- $\Delta 200, \operatorname{trp} 1-\Delta 1$, ura3- $\Delta 1$, lys 2 , ade2-101, met14, ciro & 73 \\
\hline \multirow[t]{3}{*}{ Escherichia coli } & $\mathrm{NEB} 5 \alpha$ & 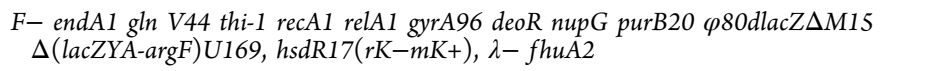 & New England Biolabs \\
\hline & Epi300 & $\begin{array}{l}F-\lambda-\text { mcrA } \Delta(\text { mrr-hsdRMS-mcrBC) } \text { (80dlacZ } \Delta M 15 \Delta(\text { lac }) X 74 \text { recA1 endA1 araD139 } \\
\Delta(\text { ara, leu }) 7697 \text { galU galK rpsL (StrR) nup } G^{\prime} \text { trfA dhfr }\end{array}$ & Epicenter \\
\hline & SW105 & $\begin{array}{c}\text { F- mcrA } \Delta(\text { mrr-hsdRMS-mcrBC) } \Phi 80 \text { dlacZ M15 } \Delta \text { lacX74 deoR recA1 endA1 araD139 } \\
\Delta(\text { ara, leu }) 7649 \text { galU } \Delta \text { galK rspL nup }[\lambda \text { cI857 (cro-bioA })<>\text { araC-PBADflpe }]\end{array}$ & 44 \\
\hline \multirow[t]{5}{*}{ Mycoplasma pneumoniae } & M129 & Wild-type & \\
\hline & GP35 & M129 tn4001:puroM438:GP35 & 17 \\
\hline & PAD014 & M129 GP35 lox71:catM438:loxm2/66 & this work \\
\hline & $\Delta 4$ & M129 GP35 $\triangle M P N 491 \Delta M P N 133 \Delta M P N 347 \Delta M P N 110$ & this work \\
\hline & PAD372PAD400 & M129 $\Delta 4$ lox71:tetM438 catM438:loxm2/66 & this work \\
\hline
\end{tabular}

reduction using synthetic DNA and GT to reduce a bacterial genome were performed on the transplantable species Mycoplasma mycoides subsp. capri (GM12). This bacterium has a genome of $1.08 \mathrm{Mbp},{ }^{66}$ and the authors could reduce it to $531 \mathrm{kbp} .{ }^{9}$ Our strategy could be used to reduce the genome of other interesting species like M. genitalium (580 kbp), ${ }^{67}$ MPN (816 kbp), ${ }^{11}$ or the model bacteriaBacillus subtilis (4.2 $\mathrm{Mbp}){ }^{68}$ These new reduced genomes will bring more insights into the minimal set of genes necessary to sustain life.

As stated above, our novel strategy is a strong tool for whole genome engineering of MPN, both for introducing metabolic pathways and to remove genes in a directed way. Together with the GP35 recombination, our technologies represent a big step toward the use of MPN in synthetic biology studies in comparison to previous technologies, restricted to random mutagenesis. To standardize these studies, we can envision introducing landing pads distributed along the MPN genome and provide a library of $S$. cerevisiae andE. coli strains containing the YAC-BACs vectors with the different genomic fragments. This will ease the editing of any gene or the introduction of DNA into different locations.

\section{MATERIALS AND METHODS}

Strains and Growth Conditions. Yeast and bacterial strains used in this work are summarized in Table 3. Wild-type yeast strains were grown at $30{ }^{\circ} \mathrm{C}$ and $190 \mathrm{rpm}$ in YPDA richmedium, whereas yeast transformants were grown in minimal SD medium depleted of tryptophan or histidine for auxotrophy complementation. E. coli strains were grown at $37{ }^{\circ} \mathrm{C}$ and 220 $\mathrm{rpm}$ in LB medium supplemented with ampicillin (100 $\mu \mathrm{g}$ $\left.\mathrm{mL}^{-1}\right)$ or chloramphenicol $\left(12.5 \mu \mathrm{g} \mathrm{mL}^{-1}\right)$ for selection of transformants. MPN strains were grown at $37{ }^{\circ} \mathrm{C}$ in SP4 medium supplemented with tetracycline $\left(5 \mu \mathrm{g} \mathrm{mL} L^{-1}\right)$, chloramphenicol $\left(50 \mu \mathrm{g} \mathrm{mL}{ }^{-1}\right)$ or gentamycin $(100 \mu \mathrm{g}$ $\mathrm{mL}^{-1}$ ) for selection of transformants.

Oligonucleotides and Amplifications. All the oligonucleotides used for this study were supplied by Eurogentec and are described in Table S3. Cloning PCRs were performed using the Q5 High-Fidelity DNA Polymerase (NEB). Screening PCRs were performed using the Advantage 2 Polymerase kit (Clontech). Multiplex PCRs were performed using the QIAGEN Multiplex PCR Kit (Qiagen).

Construction of Landing Pads and Introduction into the MPN Genome. The 500 bps upstream regions of the insertion sites for landing pads PAD014, PAD372, and PAD400 (Figure 2A and Supplementary Figure S3) were amplified with oligonucleotides LHpadxxxXho and LHpadxx$\mathrm{xEag}$ (where $\mathrm{xxx}$ designates the corresponding landing pad, see
Table S3) from MPN genomic DNA, and cleaved with XhoI and EagI restriction enzymes. The 500 bps downstream regions were amplified with oligonucleotides RHpadxxxXba and RHpadxxxEco (where $\mathrm{xxx}$ designates the corresponding landing pad, see Table S3) from MPN genomic DNA and cleaved with $X b a \mathrm{I}$ and EcoRI restriction enzymes. For the PAD014, the cat marker was amplified from pMTnCat ${ }^{25}$ with primers cmlox71Eag and cmlox2m66Xba. For the PAD372, the tet(M) marker was amplified from pMTnTet, ${ }^{69}$ with primers tetlox71Eag and tet3Xba. For the PAD400, the cat marker was amplified from $\mathrm{pMTnCat}^{25}$ with primers $\mathrm{cm} / 5 \mathrm{Eag}$ and cmlox $2 \mathrm{~m} 66 \mathrm{Xba}$. All the markers cassettes were cleaved with $E a g I$ and $X b a I$ restriction enzymes. Each upstream region, marker, and downstream region was ligated into a pBSKII (Invitrogen), previously linearized with XhoI and EcoRI, and then transformed into E. coli NEB 5alpha cells. Each landing pad was then amplified with a phosphorylated oligonucleotide and a protected oligonucleotide (the four first bases are phosphorothioate bounded, Table S3) and treated with the lambda exonuclease (Thermo) following the manufacturer's instructions to isolate single-stranded DNA. Three micrograms of ssDNA were electroporated into the corresponding MPN strain containing the GP35 recombinase following the described procedure. ${ }^{70}$ Transformant colonies were selected by antibiotic resistance and confirmed by PCR using the oligonucleotides LHpadxxxXho and RHpadxxxEco (Table S3).

Isolation and Fragmentation of MPN Genomic DNA. Genomic DNA was purified from MPN cells using the NucleoBond HMW DNA kit (Macherey-Nagel), or from genomic DNA embedded in 1\% low-melt agarose plugs and treated using the CHEF Mammalian Genomic DNA Plug Kit (Biorad). MPN genomic DNA can be embedded in agarose plugs from MPN cells or from yeast clones containing MPN genomes. ${ }^{35} \mathrm{MPN}$ genomes were released by digestion of the agarose matrix with 3 units per plug of $\beta$-Agarase I (NEB). Fragmentation by enzymatic digestion was performed with restriction enzymes from NEB following the manufacturer's instructions. When using agarose plug samples, enzymatic digestion was performed prior to the release of the genomes from the plug as described previously. ${ }^{35}$ Mechanical fragmentation by pipetting up and down was also performed, using the indications described in ref 40.

In-Yeast Assembly of pCC1 Derivatives. One microgram of linearized pCC1TRP by HpaI digestion or linearized pCC1FOS vector with EcoR72I (Lucigen) were cotransformed with $300 \mathrm{ng}$ of the PCR amplicons of the aac $\left(6^{\prime}\right)-\operatorname{aph}\left(2^{\prime \prime}\right)$ and cre cassettes, amplified from the pGmRCre vector, ${ }^{71}$ and $1.5 \mu \mathrm{g}$ of fragmented MPN genomic DNA into S. cerevisiae 
VL6-48N yeast cells following the TAR cloning protocol. ${ }^{72}$ Yeast transformant colonies were selected on SD-HIS or SDTRP agar plates containing $1 \mathrm{M}$ sorbitol. Individual colonies were picked and patched on SD-HIS or SD-TRP plates, and incubated for 2 days at $30{ }^{\circ} \mathrm{C}$. Total DNA was extracted from yeast transformants using the protocol described in ref 72 and screened by PCR using specific primers for the region cloned. Integrity of the plasmid was confirmed by Multiplex PCR.

Editing of the pCC1 Derivative Using $\lambda$ Red. The pCC1 containing the wild-type version of the mpn372mpn400 region (pCC1YTRP-gmR-37.8-cre) was transformed in the strain $E$. coli SW105 that expresses the $\lambda$ Red recombination system cloned in their chromosome. The tet $A$-sacB cassette was amplified from the E. coli T-SACK genomic DNA by PCR. The amplification was performed using oligonucleotides containing $50 \mathrm{nt}$ overhangs homologous to the targeted location of the tetA-sacB cassette in the pCC1YTRP-gmR-37.8-cre. The $\lambda$ Red system was induced as described in ref 45 and the amplicon was electroporated in induced cells. Tetracycline resistant and sucrose sensitive clones were selected on LB agar plates containing tetracycline (12.5 $\left.\mu \mathrm{g} \mathrm{mL}^{-1}\right)$ and chloramphenicol $\left(12.5 \mu \mathrm{g} \mathrm{mL}^{-1}\right)$, and containing sucrose $(6 \%)$ and chloramphenicol $\left(12.5 \mu \mathrm{g} \mathrm{mL}^{-1}\right)$, respectively. Transformants were confirmed by PCR. Then, a 70-mer oligonucleotide composed of the two 35-mer regions homologous to the regions flanking the locus to delete was electroporated. Transformant clones were selected for resistance to sucrose and sensitivity to tetracycline and were confirmed by PCR.

Editing of the pCC1 Derivative Using $\lambda$ Red. The pCC1 containing the wild-type version of the mpn372mpn400 region (pCC1YTRP-gmR-37.8-cre) was transformed in the strain E. coli SW105 that expresses the $\lambda$ Red recombination system cloned in their chromosome. The tet $A$-sacB cassette was amplified from the E. coli T-SACK genomic DNA by PCR. The amplification was performed using oligonucleotides containing $50 \mathrm{nt}$ overhangs homologous to the targeted location of the tetA-sacB cassette in the pCC1YTRP-gmR-37.8-cre. The $\lambda$ Red system was induced as described in ref 45 and the amplicon was electroporated in induced cells. Tetracycline resistant and sucrose sensitive clones were selected on LB agar plates containing tetracycline (12.5 $\left.\mu \mathrm{g} \mathrm{mL}^{-1}\right)$ and chloramphenicol $\left(12.5 \mu \mathrm{g} \mathrm{mL}^{-1}\right)$, and containing sucrose $(6 \%)$ and chloramphenicol $\left(12.5 \mu \mathrm{g} \mathrm{mL}^{-1}\right)$, respectively. Transformants were confirmed by PCR. Then, a 70-mer oligonucleotide composed of the two 35-mer regions homologous to the regions flanking the locus to delete was electroporated. Transformant clones were selected for resistance to sucrose and sensitivity to tetracycline and were confirmed by PCR.

Assembly of the Synthetic Cassettes. Eight fragments were assembled for constructing the pCC1YTRP-gmR-24.1cre and pCC1YTRP-gmR-22.4-cre vectors (Figure S6A and S6B). The complete sequence of the fragments can be found in Supplementary Figure S6C. The fragment 1, consisting of the pCC1 backbone (including the TRP1 auxotrophic marker, the chloramphenicol resistance marker, the lox66 site and the gentamycin resistance marker, respectively) was amplified by PCR from the pCC1-gmR-37.8-cre. The fragment 8, composed of the ARSH4 and CEN6 elements, was amplified by PCR from the pMT85-PStetM-pRS313. ${ }^{34}$ The synthetic fragments 2-7 were supplied by Twist Bioscience, each of them was provided cloned into a pTwist Amp Medium Copy vector. The loxm $2 / 71$ site was included in the synthetic fragment 7 . Each vector was transformed intoE. coli NEB 5-alpha and used as template for the amplification of the corresponding fragments by PCR. Finally, the 8 fragments were assembled using the Gibson Assembly Ultra Kit (Synthetic Genomics) and transformed inE. coli EPI300 following the manufacturer's instructions. Finally, the assemblies were confirmed by enzymatic digestion.

Preparation of the pCC1 Derivative and MPN Transformation. One microliter of total DNA extracted from yeast patches was electroporated into E. coli EPI300 cells (Lucigen) following the manufacturer's instructions. A transformant colony was regrown overnight in $30 \mathrm{~mL}$ of $\mathrm{LB}$ with chloramphenicol. This culture was used as inoculum of a new culture $300 \mathrm{~mL} \mathrm{LB}$ with chloramphenicol and induction solution $1 \times$ (Lucigen), which was incubated for $4 \mathrm{~h}$ in the same conditions. Then, the pCC1 derivative was purified using the NucleoBond Xtra Midi kit (Macherey-Nagel) following the manufacturer's instructions for purification of low-copy number plasmids. DNA concentration was measured using an Epoch Microplate Spectrophotometer (BioTek). Five micrograms of this plasmid were electroporated as previously described $^{70}$ in MPN strains containing the corresponding landing pads. Transformants were selected on SP4 agar medium supplemented with gentamycin and then grown in 1 $\mathrm{mL}$ of SP4 medium in 24-well plates. Genomic DNA was extracted by scrapping the cells in $100 \mu \mathrm{L}$ of water and incubating the samples at $98{ }^{\circ} \mathrm{C}$ for $10 \mathrm{~min}$. The cassette exchanges were screened by PCR. Sanger sequencing was performed by genewiz and alignments were performed using the MAFFT v7 algorithm ${ }^{74}$ and visualized with the Benchling biology software (retrieved from https://benchling.com).

\section{ASSOCIATED CONTENT}

\section{Supporting Information}

The Supporting Information is available free of charge at https://pubs.acs.org/doi/10.1021/acssynbio.0c00263.

Figure S1: pCC1YTRP map; Figure S2: Construction of an MPN strain defective for nucleases and restrictases; Figure S3: Construction of MPN M129 PAD372PAD400 strain; Figure S4: Representation of the MPN M129 genome; Figure S5: Genome editing of MPN in $E$. coli using the $\lambda$ Red system and the tet $A$-sacB counterselection; Figure S6: Construction of synthetic vectors; Table S1: Cre recognition sequences used in this work; Table S2: List of genes included in the region mpn372-mpn400; Table S3: Oligonucleotides used in this work (PDF)

\section{AUTHOR INFORMATION}

\section{Corresponding Author}

Carole Lartigue - Univ. Bordeaux, INRAE, Biologie du Fruit et Pathologie, UMR 1332, F-33140 Villenave d'Ornon, France; (1) orcid.org/0000-0001-5550-7579; Phone: +33 5571223 59; Email: carole.lartigue-prat@inrae.fr; Fax: +33 5571223 69

\section{Authors}

Luis Garcia-Morales - Univ. Bordeaux, INRAE, Biologie $d u$ Fruit et Pathologie, UMR 1332, F-33140 Villenave d'Ornon, France 
Estelle Ruiz - Univ. Bordeaux, INRAE, Biologie du Fruit et Pathologie, UMR 1332, F-33140 Villenave d'Ornon, France

Géraldine Gourgues - Univ. Bordeaux, INRAE, Biologie du Fruit et Pathologie, UMR 1332, F-33140 Villenave d'Ornon, France

Fabien Rideau - Univ. Bordeaux, INRAE, Biologie du Fruit et Pathologie, UMR 1332, F-33140 Villenave d'Ornon, France

Carlos Piñero-Lambea - Centre for Genomic Regulation (CRG), The Barcelona Institute of Science and Technology, Barcelona 08003, Spain

Maria Lluch-Senar - Centre for Genomic Regulation (CRG), The Barcelona Institute of Science and Technology, Barcelona 08003, Spain

Alain Blanchard - Univ. Bordeaux, INRAE, Biologie du Fruit et Pathologie, UMR 1332, F-33140 Villenave d'Ornon, France

Complete contact information is available at:

https://pubs.acs.org/10.1021/acssynbio.0c00263

\section{Notes}

The authors declare no competing financial interest.

\section{ACKNOWLEDGMENTS}

The authors thank Clara Blanchard for English proofreading. We also thank Dr. Don L. Court for providing biological material and advice. We acknowledge the financial support by the European Union's Horizon 2020 research and innovation program under Grant Agreement [No. 634942]; and the European MiniCell project selected by ANR, in the frame of the ERASynBio second Joint Call for Transnational Research Projects [No. ANR-15-SYNB-0001-04].

\section{ABBREVIATIONS}

MPN, Mycoplasma pneumoniae; CRISPR/Cas, clustered regularly interspaced short palindromic repeats/CRISPRassociated systems; TAR cloning, transformation-associated recombination cloning; TREC, tandem repeat coupled with endonuclease cleavage; RMCE, recombinase-mediated cassette exchange; RAGE, recombinase-assisted genome engineering; CRAGE, chassis-independent recombinase-assisted genome engineering; GT, genome transplantation; BAC, bacterial artificial chromosome; YAC, yeast artificial chromosome.

\section{REFERENCES}

(1) Adams, B. L. (2016) The Next Generation of Synthetic Biology Chassis: Moving Synthetic Biology from the Laboratory to the Field. ACS Synth. Biol. 5 (12), 1328-1330.

(2) Foley, P. L., and Shuler, M. L. (2010) Considerations for the design and construction of a synthetic platform cell for biotechnological applications. Biotechnol. Bioeng. 105 (1), 26-36.

(3) Vickers, C. E., Blank, L. M., and Kromer, J. O. (2010) Grand challenge commentary: Chassis cells for industrial biochemical production. Nat. Chem. Biol. 6 (12), 875-7.

(4) Juhas, M., Reuss, D. R., Zhu, B., and Commichau, F. M. (2014) Bacillus subtilis and Escherichia coli essential genes and minimal cell factories after one decade of genome engineering. Microbiology 160 (11), 2341-2351.

(5) Xavier, J. C., Patil, K. R., and Rocha, I. (2014) Systems biology perspectives on minimal and simpler cells. Microbiol. Mol. Biol. Rev. 78 (3), 487-509.

(6) Baby, V., Lachance, J. C., Gagnon, J., Lucier, J. F., Matteau, D., Knight, T., and Rodrigue, S. (2018) Inferring the Minimal Genome of Mesoplasma florum by Comparative Genomics and Transposon Mutagenesis. mSystems, DOI: 10.1128/mSystems.00198-17.
(7) Mushegian, A. R., and Koonin, E. V. (1996) A minimal gene set for cellular life derived by comparison of complete bacterial genomes. Proc. Natl. Acad. Sci. U. S. A. 93 (19), 10268-73.

(8) Glass, J. I., Assad-Garcia, N., Alperovich, N., Yooseph, S., Lewis, M. R., Maruf, M., Hutchison, C. A., 3rd, Smith, H. O., and Venter, J. C. (2006) Essential genes of a minimal bacterium. Proc. Natl. Acad. Sci. U. S. A. 103 (2), 425-30.

(9) Hutchison, C. A., 3rd, Chuang, R. Y., Noskov, V. N., AssadGarcia, N., Deerinck, T. J., Ellisman, M. H., Gill, J., Kannan, K., Karas, B. J., Ma, L., Pelletier, J. F., Qi, Z. Q., Richter, R. A., Strychalski, E. A., Sun, L., Suzuki, Y., Tsvetanova, B., Wise, K. S., Smith, H. O., Glass, J. I., Merryman, C., Gibson, D. G., and Venter, J. C. (2016) Design and synthesis of a minimal bacterial genome. Science 351 (6280), No. aad6253.

(10) Breuer, M., Earnest, T. M., Merryman, C., Wise, K. S., Sun, L., Lynott, M. R., Hutchison, C. A., Smith, H. O., Lapek, J. D., Gonzalez, D. J., de Crecy-Lagard, V., Haas, D., Hanson, A. D., Labhsetwar, P., Glass, J. I., and Luthey-Schulten, Z. (2019) Essential metabolism for a minimal cell. eLife, DOI: 10.7554/eLife.36842.

(11) Himmelreich, R., Hilbert, H., Plagens, H., Pirkl, E., Li, B. C., and Herrmann, R. (1996) Complete sequence analysis of the genome of the bacterium Mycoplasma pneumoniae. Nucleic Acids Res. 24 (22), 4420-49.

(12) Waites, K. B., and Talkington, D. F. (2004) Mycoplasma pneumoniae and its role as a human pathogen. Clin. Microbiol. Rev. 17 (4), 697-728.

(13) Pollack, J. D., Williams, M. V., and McElhaney, R. N. (1997) The comparative metabolism of the mollicutes (Mycoplasmas): the utility for taxonomic classification and the relationship of putative gene annotation and phylogeny to enzymatic function in the smallest free-living cells. Crit. Rev. Microbiol. 23 (4), 269-354.

(14) Kuhner, S., van Noort, V., Betts, M. J., Leo-Macias, A., Batisse, C., Rode, M., Yamada, T., Maier, T., Bader, S., Beltran-Alvarez, P., Castano-Diez, D., Chen, W. H., Devos, D., Guell, M., Norambuena, T., Racke, I., Rybin, V., Schmidt, A., Yus, E., Aebersold, R., Herrmann, R., Bottcher, B., Frangakis, A. S., Russell, R. B., Serrano, L., Bork, P., and Gavin, A. C. (2009) Proteome organization in a genome-reduced bacterium. Science 326 (5957), 1235-1240.

(15) Guell, M., van Noort, V., Yus, E., Chen, W. H., Leigh-Bell, J., Michalodimitrakis, K., Yamada, T., Arumugam, M., Doerks, T., Kuhner, S., Rode, M., Suyama, M., Schmidt, S., Gavin, A. C., Bork, P., and Serrano, L. (2009) Transcriptome complexity in a genomereduced bacterium. Science 326 (5957), 1268-1271.

(16) Yus, E., Maier, T., Michalodimitrakis, K., van Noort, V., Yamada, T., Chen, W. H., Wodke, J. A., Guell, M., Martinez, S., Bourgeois, R., Kuhner, S., Raineri, E., Letunic, I., Kalinina, O. V., Rode, M., Herrmann, R., Gutierrez-Gallego, R., Russell, R. B., Gavin, A. C., Bork, P., and Serrano, L. (2009) Impact of genome reduction on bacterial metabolism and its regulation. Science 326 (5957), 12631268.

(17) Pinero-Lambea, C., Garcia-Ramallo, E., Martinez, S., Delgado, J., Serrano, L., and Lluch-Senar, M. (2020) Mycoplasma pneumoniae Genome Editing Based on Oligo Recombineering and Cas9-Mediated Counterselection. ACS Synth. Biol. 9 (7), 1693-1704.

(18) Lluch-Senar, M., Delgado, J., Chen, W. H., Llorens-Rico, V., O’Reilly, F. J., Wodke, J. A., Unal, E. B., Yus, E., Martinez, S., Nichols, R. J., Ferrar, T., Vivancos, A., Schmeisky, A., Stulke, J., van Noort, V., Gavin, A. C., Bork, P., and Serrano, L. (2015) Defining a minimal cell: essentiality of small ORFs and ncRNAs in a genome-reduced bacterium. Mol. Syst. Biol. 11 (1), 780.

(19) Hasselbring, B. M., Page, C. A., Sheppard, E. S., and Krause, D. C. (2006) Transposon mutagenesis identifies genes associated with Mycoplasma pneumoniae gliding motility. J. Bacteriol. 188 (17), 6335-45.

(20) Hasselbring, B. M., Sheppard, E. S., and Krause, D. C. (2012) P65 truncation impacts P30 dynamics during Mycoplasma pneumoniae gliding. J. Bacteriol. 194 (11), 3000-7.

(21) Feng, M., Schaff, A. C., Cuadra Aruguete, S. A., Riggs, H. E., Distelhorst, S. L., and Balish, M. F. (2018) Development of 
Mycoplasma pneumoniae biofilms in vitro and the limited role of motility. Int. J. Med. Microbiol. 308 (3), 324-334.

(22) Torres-Puig, S., Martinez-Torro, C., Granero-Moya, I., Querol, E., Pinol, J., and Pich, O. Q. (2018) Activation of sigma20-dependent recombination and horizontal gene transfer in Mycoplasma genitalium. DNA Res. 25 (4), 383-393.

(23) Garcia-Morales, L., Gonzalez-Gonzalez, L., Querol, E., and Pinol, J. (2016) A minimized motile machinery for Mycoplasma genitalium. Mol. Microbiol. 100 (1), 125-38.

(24) Torres-Puig, S., Broto, A., Querol, E., Pinol, J., and Pich, O. Q. (2015) A novel sigma factor reveals a unique regulon controlling cellspecific recombination in Mycoplasma genitalium. Nucleic Acids Res. 43 (10), 4923-36.

(25) Calisto, B. M., Broto, A., Martinelli, L., Querol, E., Pinol, J., and Fita, I. (2012) The EAGR box structure: a motif involved in mycoplasma motility. Mol. Microbiol. 86 (2), 382-93.

(26) Dhandayuthapani, S., Rasmussen, W. G., and Baseman, J. B. (1999) Disruption of gene mg218 of Mycoplasma genitalium through homologous recombination leads to an adherence-deficient phenotype. Proc. Natl. Acad. Sci. U. S. A. 96 (9), 5227-32.

(27) Krishnakumar, R., Assad-Garcia, N., Benders, G. A., Phan, Q., Montague, M. G., and Glass, J. I. (2010) Targeted chromosomal knockouts in Mycoplasma pneumoniae. Appl. Environ. Microbiol. 76 (15), 5297-9.

(28) Sun, Z., Deng, A., Hu, T., Wu, J., Sun, Q., Bai, H., Zhang, G., and Wen, T. (2015) A high-efficiency recombineering system with PCR-based ssDNA in Bacillus subtilis mediated by the native phage recombinase GP35. Appl. Microbiol. Biotechnol. 99 (12), 5151-62.

(29) Tsarmpopoulos, I., Gourgues, G., Blanchard, A., Vashee, S., Jores, J., Lartigue, C., and Sirand-Pugnet, P. (2016) In-Yeast Engineering of a Bacterial Genome Using CRISPR/Cas9. ACS Synth. Biol. 5 (1), 104-9.

(30) Chandran, S., Noskov, V. N., Segall-Shapiro, T. H., Ma, L., Whiteis, C., Lartigue, C., Jores, J., Vashee, S., and Chuang, R. Y. (2014) TREC-IN: gene knock-in genetic tool for genomes cloned in yeast. BMC Genomics 15, 1180.

(31) Lartigue, C., Valverde Timana, Y., Labroussaa, F., Schieck, E., Liljander, A., Sacchini, F., Posthaus, H., Batailler, B., Sirand-Pugnet, P., Vashee, S., Jores, J., and Blanchard, A. (2019) Attenuation of a Pathogenic Mycoplasma Strain by Modification of the obg Gene by Using Synthetic Biology Approaches. mSphere, DOI: 10.1128/ mSphere.00030-19.

(32) Jores, J., Ma, L., Ssajjakambwe, P., Schieck, E., Liljander, A., Chandran, S., Stoffel, M. H., Cippa, V., Arfi, Y., Assad-Garcia, N., Falquet, L., Sirand-Pugnet, P., Blanchard, A., Lartigue, C., Posthaus, H., Labroussaa, F., and Vashee, S. (2019) Removal of a Subset of Non-essential Genes Fully Attenuates a Highly Virulent Mycoplasma Strain. Front. Microbiol. 10, 664.

(33) Lartigue, C., Vashee, S., Algire, M. A., Chuang, R. Y., Benders, G. A., Ma, L., Noskov, V. N., Denisova, E. A., Gibson, D. G., AssadGarcia, N., Alperovich, N., Thomas, D. W., Merryman, C., Hutchison, C. A., 3rd, Smith, H. O., Venter, J. C., and Glass, J. I. (2009) Creating bacterial strains from genomes that have been cloned and engineered in yeast. Science 325 (5948), 1693-6.

(34) Labroussaa, F., Lebaudy, A., Baby, V., Gourgues, G., Matteau, D., Vashee, S., Sirand-Pugnet, P., Rodrigue, S., and Lartigue, C. (2016) Impact of donor-recipient phylogenetic distance on bacterial genome transplantation. Nucleic Acids Res. 44 (17), 8501-11.

(35) Ruiz, E., Talenton, V., Dubrana, M. P., Guesdon, G., LluchSenar, M., Salin, F., Sirand-Pugnet, P., Arfi, Y., and Lartigue, C. (2019) CReasPy-Cloning: A Method for Simultaneous Cloning and Engineering of Megabase-Sized Genomes in Yeast Using the CRISPRCas9 System. ACS Synth. Biol. 8, 2547.

(36) Santos, C. N., Regitsky, D. D., and Yoshikuni, Y. (2013) Implementation of stable and complex biological systems through recombinase-assisted genome engineering. Nat. Commun. 4, 2503.

(37) Santos, C. N., and Yoshikuni, Y. (2014) Engineering complex biological systems in bacteria through recombinase-assisted genome engineering. Nat. Protoc. 9 (6), 1320-36.
(38) Wang, G., Zhao, Z., Ke, J., Engel, Y., Shi, Y. M., Robinson, D., Bingol, K., Zhang, Z., Bowen, B., Louie, K., Wang, B., Evans, R., Miyamoto, Y., Cheng, K., Kosina, S., De Raad, M., Silva, L., Luhrs, A., Lubbe, A., Hoyt, D. W., Francavilla, C., Otani, H., Deutsch, S., Washton, N. M., Rubin, E. M., Mouncey, N. J., Visel, A., Northen, T., Cheng, J. F., Bode, H. B., and Yoshikuni, Y. (2019) CRAGE enables rapid activation of biosynthetic gene clusters in undomesticated bacteria. Nat. Microbiol 4 (12), 2498-2510.

(39) Orr-Weaver, T. L., Szostak, J. W., and Rothstein, R. J. (1981) Yeast transformation: a model system for the study of recombination. Proc. Natl. Acad. Sci. U. S. A. 78 (10), 6354-8.

(40) Leem, S. H., Noskov, V. N., Park, J. E., Kim, S. I., Larionov, V., and Kouprina, N. (2003) Optimum conditions for selective isolation of genes from complex genomes by transformation-associated recombination cloning. Nucleic Acids Res. 31 (6), No. e29.

(41) Kannan, T. R., and Baseman, J. B. (2006) ADP-ribosylating and vacuolating cytotoxin of Mycoplasma pneumoniae represents unique virulence determinant among bacterial pathogens. Proc. Natl. Acad. Sci. U. S. A. 103 (17), 6724-9.

(42) Grover, R. K., Zhu, X., Nieusma, T., Jones, T., Boreo, I., MacLeod, A. S., Mark, A., Niessen, S., Kim, H. J., Kong, L., AssadGarcia, N., Kwon, K., Chesi, M., Smider, V. V., Salomon, D. R., Jelinek, D. F., Kyle, R. A., Pyles, R. B., Glass, J. I., Ward, A. B., Wilson, I. A., and Lerner, R. A. (2014) A structurally distinct human mycoplasma protein that generically blocks antigen-antibody union. Science 343 (6171), 656-661.

(43) Blotz, C., Singh, N., Dumke, R., and Stulke, J. (2020) Characterization of an Immunoglobulin Binding Protein (IbpM) From Mycoplasma pneumoniae. Front. Microbiol. 11, 685.

(44) Warming, S., Costantino, N., Court, D. L., Jenkins, N. A., and Copeland, N. G. (2005) Simple and highly efficient BAC recombineering using galK selection. Nucleic Acids Res. 33 (4), No. e36.

(45) Sharan, S. K., Thomason, L. C., Kuznetsov, S. G., and Court, D. L. (2009) Recombineering: a homologous recombination-based method of genetic engineering. Nat. Protoc. 4 (2), 206-23.

(46) Li, X. T., Thomason, L. C., Sawitzke, J. A., Costantino, N., and Court, D. L. (2013) Positive and negative selection using the tetAsacB cassette: recombineering and P1 transduction in Escherichia coli. Nucleic Acids Res. 41 (22), No. e204.

(47) Hutchison, C. A., Peterson, S. N., Gill, S. R., Cline, R. T. White, O., Fraser, C. M., Smith, H. O., and Venter, J. C. (1999) Global transposon mutagenesis and a minimal Mycoplasma genome. Science 286 (5447), 2165-9.

(48) Hutchison, C. A., Merryman, C., Sun, L., Assad-Garcia, N., Richter, R. A., Smith, H. O., and Glass, J. I. (2019) Polar Effects of Transposon Insertion into a Minimal Bacterial Genome. J. Bacteriol., DOI: $10.1128 /$ JB.00185-19.

(49) Balish, M. F. (2014) Mycoplasma pneumoniae, an underutilized model for bacterial cell biology. J. Bacteriol. 196 (21), 3675-82.

(50) Hou, Z., Zhou, Z., Wang, Z., and Xiao, G. (2016) Assembly of long DNA sequences using a new synthetic Escherichia coli-yeast shuttle vector. Virol. Sin. 31 (2), 160-7.

(51) Somarajan, S. R., Kannan, T. R., and Baseman, J. B. (2010) Mycoplasma pneumoniae Mpn133 is a cytotoxic nuclease with a glutamic acid-, lysine- and serine-rich region essential for binding and internalization but not enzymatic activity. Cell. Microbiol. 12 (12), 1821-31.

(52) Yamamoto, T., Kida, Y., Sakamoto, Y., and Kuwano, K. (2017) Mpn491, a secreted nuclease of Mycoplasma pneumoniae, plays a critical role in evading killing by neutrophil extracellular traps. Cell. Microbiol. 19 (3), e12666.

(53) Seybert, A., Herrmann, R., and Frangakis, A. S. (2006) Structural analysis of Mycoplasma pneumoniae by cryo-electron tomography. J. Struct. Biol. 156 (2), 342-54.

(54) Hedreyda, C. T., Lee, K. K., and Krause, D. C. (1993) Transformation of Mycoplasma pneumoniae with Tn4001 by electroporation. Plasmid 30 (2), 170-5. 
(55) Willby, M. J., and Krause, D. C. (2002) Characterization of a Mycoplasma pneumoniae hmw3 mutant: implications for attachment organelle assembly. J. Bacteriol. 184 (11), 3061-8.

(56) Hedreyda, C. T., and Krause, D. C. (1995) Identification of a possible cytadherence regulatory locus in Mycoplasma pneumoniae. Infect. Immun. 63 (9), 3479-83.

(57) Fredens, J., Wang, K., de la Torre, D., Funke, L. F. H., Robertson, W. E., Christova, Y., Chia, T., Schmied, W. H., Dunkelmann, D. L., Beranek, V., Uttamapinant, C., Llamazares, A. G., Elliott, T. S., and Chin, J. W. (2019) Total synthesis of Escherichia coli with a recoded genome. Nature 569 (7757), 514-518.

(58) Heil, J. R., Cheng, J., and Charles, T. C. (2012) Site-specific bacterial chromosome engineering: PhiC31 integrase mediated cassette exchange (IMCE). J. Visualized Exp., DOI: 10.3791/3698.

(59) Krishnakumar, R., Grose, C., Haft, D. H., Zaveri, J., Alperovich, N., Gibson, D. G., Merryman, C., and Glass, J. I. (2014) Simultaneous non-contiguous deletions using large synthetic DNA and site-specific recombinases. Nucleic Acids Res. 42 (14), No. e111.

(60) Noskov, V. N., Ma, L., Chen, S., and Chuang, R. Y. (2015) Recombinase-mediated cassette exchange (RMCE) system for functional genomics studies in Mycoplasma mycoides. Biol. Proced. Online 17, 6.

(61) Hoang, T. T., Karkhoff-Schweizer, R. R., Kutchma, A. J., and Schweizer, H. P. (1998) A broad-host-range Flp-FRT recombination system for site-specific excision of chromosomally-located DNA sequences: application for isolation of unmarked Pseudomonas aeruginosa mutants. Gene 212 (1), 77-86.

(62) Schetelig, M. F., Yan, Y., Zhao, Y., and Handler, A. M. (2019) Genomic targeting by recombinase-mediated cassette exchange in the spotted wing drosophila, Drosophila suzukii. Insect Mol. Biol. 28 (2), 187-195.

(63) Soares, H. R., Almeida, A. I., Tomas, H. A., Alves, P. M., and Coroadinha, A. S. (2018) Flexible pseudotyping of retrovirus using recombinase-mediated cassette exchange. Biotechnol. Lett. 40 (4), 633-639.

(64) Kolb, A. F., Knowles, C., Pultinevicius, P., Harbottle, J. A., Petrie, L., Robinson, C., and Sorrell, D. A. (2017) RecombinaseMediated Cassette Exchange Using Adenoviral Vectors. Methods Mol. Biol. 1642, 127-150.

(65) Roebroek, A. J., and Van Gool, B. (2014) Generation of an allelic series of knock-in mice using recombinase-mediated cassette exchange (RMCE). Methods Mol. Biol. 1194, 63-76.

(66) Gibson, D. G., Glass, J. I., Lartigue, C., Noskov, V. N., Chuang, R. Y., Algire, M. A., Benders, G. A., Montague, M. G., Ma, L., Moodie, M. M., Merryman, C., Vashee, S., Krishnakumar, R., Assad-Garcia, N., Andrews-Pfannkoch, C., Denisova, E. A., Young, L., Qi, Z. Q., SegallShapiro, T. H., Calvey, C. H., Parmar, P. P., Hutchison, C. A., 3rd, Smith, H. O., and Venter, J. C. (2010) Creation of a bacterial cell controlled by a chemically synthesized genome. Science 329 (5987), $52-6$.

(67) Fraser, C. M., Gocayne, J. D., White, O., Adams, M. D., Clayton, R. A., Fleischmann, R. D., Bult, C. J., Kerlavage, A. R., Sutton, G., Kelley, J. M., Fritchman, R. D., Weidman, J. F., Small, K. V., Sandusky, M., Fuhrmann, J., Nguyen, D., Utterback, T. R., Saudek, D. M., Phillips, C. A., Merrick, J. M., Tomb, J. F., Dougherty, B. A., Bott, K. F., Hu, P. C., Lucier, T. S., Peterson, S. N., Smith, H. O., Hutchison, C. A., 3rd, and Venter, J. C. (1995) The minimal gene complement of Mycoplasma genitalium. Science 270 (5235), 397403.

(68) Kunst, F., Ogasawara, N., Moszer, I., Albertini, A. M., Alloni, G., Azevedo, V., Bertero, M. G., Bessieres, P., Bolotin, A., Borchert, S., Borriss, R., Boursier, L., Brans, A., Braun, M., Brignell, S. C., Bron, S., Brouillet, S., Bruschi, C. V., Caldwell, B., Capuano, V., Carter, N. M., Choi, S. K., Cordani, J. J., Connerton, I. F., Cummings, N. J., Daniel, R. A., Denziot, F., Devine, K. M., Dusterhoft, A., Ehrlich, S. D., Emmerson, P. T., Entian, K. D., Errington, J., Fabret, C., Ferrari, E., Foulger, D., Fritz, C., Fujita, M., Fujita, Y., Fuma, S., Galizzi, A., Galleron, N., Ghim, S. Y., Glaser, P., Goffeau, A., Golightly, E. J., Grandi, G., Guiseppi, G., Guy, B. J., Haga, K., Haiech, J., Harwood, C.
R., Henaut, A., Hilbert, H., Holsappel, S., Hosono, S., Hullo, M. F., Itaya, M., Jones, L., Joris, B., Karamata, D., Kasahara, Y., KlaerrBlanchard, M., Klein, C., Kobayashi, Y., Koetter, P., Koningstein, G., Krogh, S., Kumano, M., Kurita, K., Lapidus, A., Lardinois, S., Lauber, J., Lazarevic, V., Lee, S. M., Levine, A., Liu, H., Masuda, S., Mauel, C., Medigue, C., Medina, N., Mellado, R. P., Mizuno, M., Moestl, D., Nakai, S., Noback, M., Noone, D., O’Reilly, M., Ogawa, K., Ogiwara, A., Oudega, B., Park, S. H., Parro, V., Pohl, T. M., Portelle, D., Porwollik, S., Prescott, A. M., Presecan, E., Pujic, P., Purnelle, B., Rapoport, G., Rey, M., Reynolds, S., Rieger, M., Rivolta, C., Rocha, E., Roche, B., Rose, M., Sadaie, Y., Sato, T., Scanlan, E., Schleich, S., Schroeter, R., Scoffone, F., Sekiguchi, J., Sekowska, A., Seror, S. J., Serror, P., Shin, B. S., Soldo, B., Sorokin, A., Tacconi, E., Takagi, T., Takahashi, H., Takemaru, K., Takeuchi, M., Tamakoshi, A., Tanaka, T., Terpstra, P., Togoni, A., Tosato, V., Uchiyama, S., Vandebol, M., Vannier, F., Vassarotti, A., Viari, A., Wambutt, R., Wedler, H., Weitzenegger, T., Winters, P., Wipat, A., Yamamoto, H., Yamane, K., Yasumoto, K., Yata, K., Yoshida, K., Yoshikawa, H. F., Zumstein, E., Yoshikawa, H., and Danchin, A. (1997) The complete genome sequence of the gram-positive bacterium Bacillus subtilis. Nature 390 (6657), 249-256.

(69) Pich, O. Q., Burgos, R., Planell, R., Querol, E., and Pinol, J. (2006) Comparative analysis of antibiotic resistance gene markers in Mycoplasma genitalium: application to studies of the minimal gene complement. Microbiology 152 (2), 519-527.

(70) Reddy, S. P., Rasmussen, W. G., and Baseman, J. B. (1996) Isolation and characterization of transposon Tn4001-generated, cytadherence-deficient transformants of Mycoplasma pneumoniae and Mycoplasma genitalium. FEMS Immunol. Med. Microbiol. 15 (4), 199-211.

(71) Mariscal, A. M., Gonzalez-Gonzalez, L., Querol, E., and Pinol, J. (2016) All-in-one construct for genome engineering using Cre-lox technology. DNA Res. 23 (3), 263-70.

(72) Kouprina, N., and Larionov, V. (2008) Selective isolation of genomic loci from complex genomes by transformation-associated recombination cloning in the yeast Saccharomyces cerevisiae. Nat. Protoc. 3 (3), 371-7.

(73) Larionov, V., Kouprina, N., Solomon, G., Barrett, J. C., and Resnick, M. A. (1997) Direct isolation of human BRCA2 gene by transformation-associated recombination in yeast. Proc. Natl. Acad. Sci. U. S. A. 94 (14), 7384-7.

(74) Katoh, K., and Standley, D. M. (2013) MAFFT multiple sequence alignment software version 7 : improvements in performance and usability. Mol. Biol. Evol. 30 (4), 772-80. 